\section{Starting again from scratch}

\section{London}

THE Iraqi occupation of Kuwait has left the scientific infrastructure of that country, formerly among the most advanced in the Arab world, in a shambles, and Kuwaiti scientists now face the unenviable task of rebuilding from almost nothing.

Restoring Kuwait's laboratories, gutted during the occupation, will take tens of millions of dollars, and the effort seems sure to be delayed until a good start has been made on the more pressing need of restoring the country's basic infrastructure. But an even more difficult task will be replacing the nowdeparted army of foreign scientists and technicians who made up a large proportion of Kuwait's scientific workforce. Many of those workers seem likely to stay away, at least until the political and physical environments return to normal.

Little is left at Kuwait's two important centres for research, Kuwait University and the Kuwait Institute for Scientific Research (KISR). During the occupation, Iraqi soldiers and scientists systematically looted them of equipment, books and journals, according to many reports from Kuwait (see, for example, Nature 349, 450; 7 February 1991). Staff from the University of Basra, Iraq, are reported to have removed thousands of personal computers from KISR. Gisli Sigurdsson, formerly of the university's teaching hospital, says that Iraqui scientists he recognized from scientific meetings were among those he saw taking equipment and teaching materials from the hospital.

Before the invasion, Kuwait's laboratories were the equal of many in North America and Western Europe, says David Britt, a former Kuwait University faculty member who has been running a newsletter from Liverpool for the university's disbanded staff. By contrast, the university laboratories Britt has visited in Baghdad were of "secondary school standard", in Western terms - which may explain why Iraqi scientists were willing to take part in the theft of Kuwait's facilities.

Most university and KISR buildings are now reported to be intact, but empty. Gary Burns, formerly of Kuwait University Medical School and now at the Free University of Berlin, says he witnessed the looting of the Medical School library. "Even the shelving" was taken, he says.

Kuwaiti scientists realize that rebuilding their laboratories is likely to take several years, as bringing back basic services, such as water and electricity supplies, and extinguishing the hundreds of fires across Kuwait's sabotaged oil fields will take precedence. Abdullatif Al-Bader, dean of the Kuwait Medical School, predicts that restoring that school to its pre-invasion state is likely to take some three years. Al-Bader, who was stranded in Montreal when Iraq invaded, expects to return to Kuwait within the next six weeks to assess the precise extent of the damage.

The university is a more urgent concern than KISR, mainly because of its teaching function. The short-term priority, says Ali Trarh, from the Kuwait University office at the Washington embassy, is to find temporary places for as many students as possible at universities in the other Gulf states.

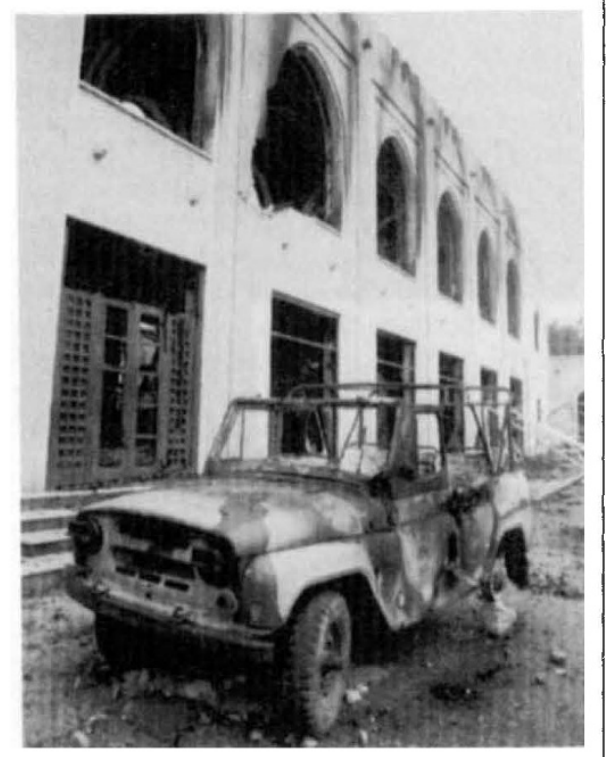

Devastation in Kuwait City.

Replacing journal back issues and out-ofprint books will be a major problem. But the departure of the majority of university and KISR staff is a greater worry. Given the cur-

\section{London}

IN the wake of the Palestine Liberation Organization's support for Saddam Hussein during the Gulf crisis, many human rights groups are fearing a backlash against Kuwait's large Palestinian population. Palestinian students and researchers may find themselves discriminated against in the postwar rebuilding of Kuwait.

At Kuwait University, former staff members say that they fear the Kuwaitis' hostility towards Palestinians will bar many of the university's best students from completing their courses. Before the Iraqi invasion, Kuwaiti citizens were just barely a majority of the university's 17,000 students, despite the preferential treatment given to Kuwaiti applicants. Most of the rest were other Arabs, especially Palestinians.

The Palestinians tended to be the university's best students, says David Britt, formerly of the faculty of allied health, but he fears that they will not be welcomed back. With the university gutted, its students will have to find temporary places at schools in the other Gulf states, but there are too few rent political instability and widespread air pollution in Kuwait (see Nature 350, 98; 14 March 1991), Burns believes many may not wish to return.

Adnan Shihab-Eldin, a senior KISR researcher who was visiting the Lawrence Berkeley Laboratory in California at the time of the invasion, estimates that only 10 15 per cent of KISR's 1,000-plus staff now remain in Kuwait. "I'd be amazed if more than 50 per cent of the original staff return", he says. But Al-Bader is more optimistic about the return of the medical school's staff. Only two of the 120 staff members he has been in contact with have so far taken other permanent jobs.

Shihab-Eldin would like to see groups of researchers from foreign institutes whose research interests overlap with those of KISR visit Kuwait for short periods to help with KISR's restoration. He believes that all of Kuwait's institutions will suffer without help from foreign nationals. Native Kuwaitis must accept this, and give foreigners who wish to help the opportunity to take full Kuwaiti citizenship (something that rarely happened in pre-invasion Kuwait), or else must work much harder than they are accustomed to rebuild their shattered country, Shihab Eldin says.

Statements by Kuwaiti officials indicate a preference for the latter course. The Kuwaiti government aims to ensure that a majority of the country's postwar population is native Kuwaiti. Before the Iraqi invasion, Kuwaitis made up only $30-40$ per cent of a population of some 2 million.

Peter Aldhous

\title{
Palestinians may be barred from courses
}

places to accommodate all the students, says Ali Trarh, from the Kuwait University office in Washington. In finding places for students, preference must be given to native Kuwaitis, Trarh says.

"Many students face the prospect of finding nowhere to go", says Gary Burns, formerly of the medical school. "It's desperately upsetting."

The anti-Palestinian feeling may also affect the Kuwait Institute for Scientific Research (KISR). Before the invasion, the majority of KISR staff were foreign nationals, including a large number of $\mathrm{Pa}$ lestinians. Richard Wilson, from Harvard University, a regular visitor to KISR over the past decade, fears that this memory may place KISR's restoration low on the Kuwaiti government's list of priorities. Ironically, Wilson says, the expertise of KISR's former staff would be particularly valuable in solving Kuwait's immediate problems. KISR researchers concentrated on applied research, including work into air pollution, seawater desalination and petroleum technology.

PeterAldhous 